\title{
Cleidocranial dysostosis: a report on two familial cases*
}

Disostose cleidocraniana: relato de dois casos familiares

\author{
Carlos Guilherme Gaelzer Porciuncula ${ }^{1}$, Ricardo Ferreira de Lira ${ }^{2}$, Maria Lúcia Lima Soares ${ }^{3}$, \\ Diego Lisboa Araújo², Lucas Rocha Mota ${ }^{4}$, Larine Ferreira Lira ${ }^{5}$
}

\begin{abstract}
Cleidocranial dysostosis is a rare genetic syndrome with an autosomal dominant inheritance pattern. The most common manifestations include clavicular aplasia or hypoplasia, open fontanelles and abnormal dentition. The present report describes two familial cases whose late diagnosis was made by means of clinical and radiographic findings. The treatment was radical, with complete surgical teeth extraction and making of total dental prosthesis.
\end{abstract}

Keywords: Cleidocranial dysplasia; Hypoplasia of clavicles; Supernumerary teeth.

Resumo Disostose cleidocraniana é uma síndrome genética rara com padrão de herança autossômica dominante. Suas manifestações mais comuns são aplasia ou hipoplasia de clavículas, fontanelas abertas e dentição anômala. Este estudo relata dois casos clínicos familiares cujo diagnóstico foi feito tardiamente por meio de achados clínicos e radiográficos. Foi feito tratamento radical com remoção dos dentes e confecção de prótese total.

Unitermos: Disostose cleidocraniana; Hipoplasia de clavícula; Dentes extranumerários.

Porciuncula CGG, Lira RF, Soares MLL, Araújo DL, Mota LR, Lira LF. Cleidocranial dysostosis: a report on two familial cases. Radiol Bras. 2013 Nov/Dez;46(6):382-384.

\section{INTRODUCTION}

Cleidocranial dysostosis is a rare genetic disorder with a prevalence ranging from $1: 200,000^{(\mathbf{1})}$ to $1: 1,000,000^{(2)}$. It is characterized by developmental alterations in the clavicles, cranial and facial bones, teeth and in other bones, involving practically the whole skeleton $^{(3)}$, and presents an autosomal dominant inheritance pattern, with no predilection for sex or race ${ }^{(4)}$. Such disorder is caused by a defect in the CBFA 1 gene that is present in the $6 \mathrm{p} 21$ chromosome; and this gene guides the differentiation of osteoblast precursor cells, playing an essential role in the development of both endo-

* Study developed at Hospital Universitário Professor Alberto Antunes - Universidade Federal de Alagoas (HUPAA-UFAL), Maceió, AL, Brazil.

1. PhD, MD, Geneticist, Associate Professor of Medical and Clinical Genetics, School of Medicine, Universidade Federal de Alagoas (UFAL), Maceió, AL, Brazil.

2. Graduate Students of Medicine, Universidade Federal de Alagoas (UFAL), Maceió, AL, Brazil.

3. Neuroradiologist, Professor of Radiology and Imaging Diagnosis, School of Medicine, Universidade Federal de Alagoas (UFAL), Maceió, AL, Brazil.

4. Graduate Student of Biological Sciences, Universidade Federal de Alagoas (UFAL), Maceió, AL, Brazil.

5. Graduate Student of Dentistry, Universidade Federal de Alagoas (UFAL), Maceió, AL, Brazil.

Mailing Address: Ricardo Ferreira de Lira. Avenida Durval de Góes Monteiro, 4229, Condomínio Village Planalto, Quadra A, Casa 135, Tabuleiro dos Martins. Maceió, AL, Brazil, 57061-290. E-mail: ricardo_flira@hotmail.com.

Received March 8, 2013. Accepted after revision May 10, 2013. chondral and membranous bone tissues. It may be related to delayed ossification of the skull, pelvis and extremities in cases of cleidocranial dysostosis ${ }^{(4)}$. The diagnosis of such disorder is based on clinical and radiological findings, and the following triad is considered pathognomonic: presence of multiple supernumerary teeth; partial or total absence of the clavicles; and open sagittal suture and fontanelles. In the absence of any of such findings one should consider other disorders for a possible differential diagnosis such as pycnodysostosis that is different from cleidocranial dysostosis for the presence of bones fragility, nanism and partial agenesis of hand and foot phalanges ${ }^{(5,6)}$.

The present study is aimed at reporting two cases of cleidocranial dysostosis in a single family, as well as describing clinical and radiological findings which allow the diagnosis.

\section{CASES REPORT}

A 28-year-old, male patient with history of supernumerary teeth and dysmorphic signs was referred by the School of Odontology - Universidade Federal de Alagoas for consultation with the geneticist. At the anamnesis, the patient complained of a "lump" in the left maxillary region whose development had occurred after exodontics in that region. At physical examination, the following findings were observed: low stature, cranial bones bulging and failure in fontanelles closure, subtle exophthalmos, middle facial third hypoplasia, ogival palate, occlusal disharmony, and multiple carious lesions. Cephalometrics demonstrated cephalic perimeter corresponding to $60 \mathrm{~cm}$ with brachycephalus. Panoramic radiography demonstrated the presence of multiple unerupted teeth, with retained permanent teeth, innumerable supernumerary teeth and dentigerous cysts (Figure 1).

Skull radiography showed parietal and frontal bones bulging with depressed median sagittal sulcus, corresponding to persistence of the anterior fontanelle (Figure 2).

Clavicular hypoplasia that had been observed at physical examination, was also confirmed by means of radiography. The shoulders mobility was unusual and the patient was able to move them to the midline. Skeletal alterations were also identified at pelvis radiography, revealing failure in the pubic symphysis ossification and deformity of the left hip, suggesting the presence of a sequel from metaphyseal dysplasia.

The patient reported, in his familial history, many relatives with similar characteristics. The heredogram demonstrated the 


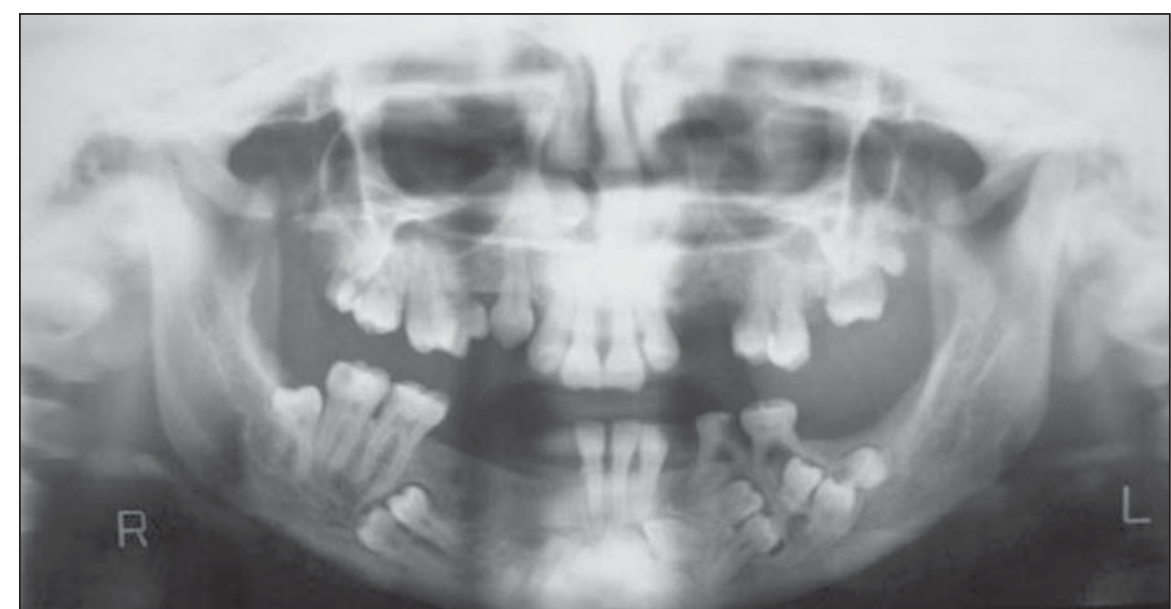

Figure 1. Panoramic radiography showing deciduous teeth permanence and unerupted permanent teeth, besides the presence of multiple supernumerary teeth and numerous dentigerous cysts. Maxillary hypoplasia and hypoplastic zygomatic arch.
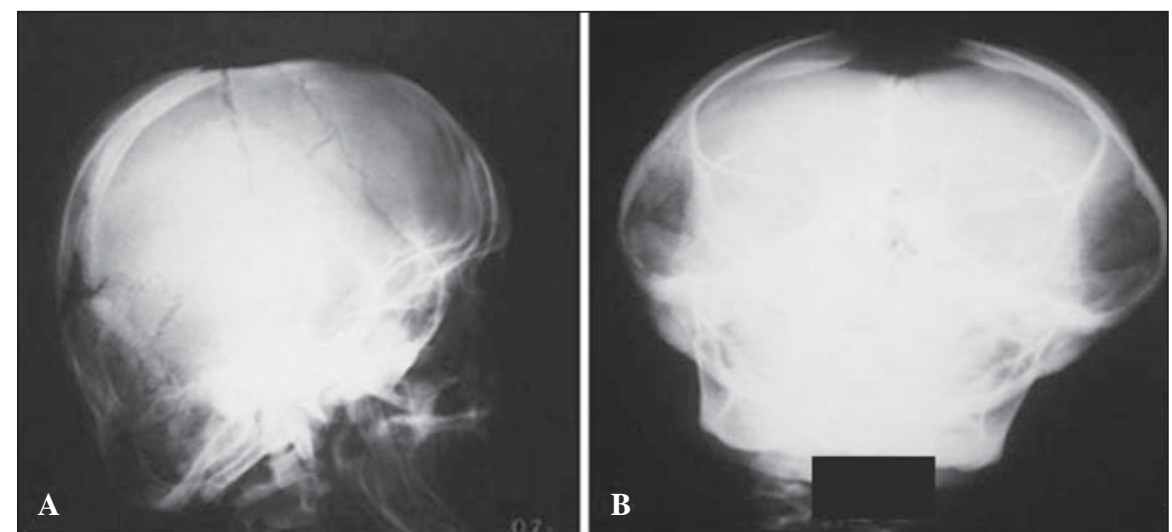

Figure 2. Cranial radiography demonstrating macrocrania, brachycephalus with frontal and parietal bones bulging, and persistence of anterior fontanelle, besides Wormian bones and mastoid hypopneumatization.

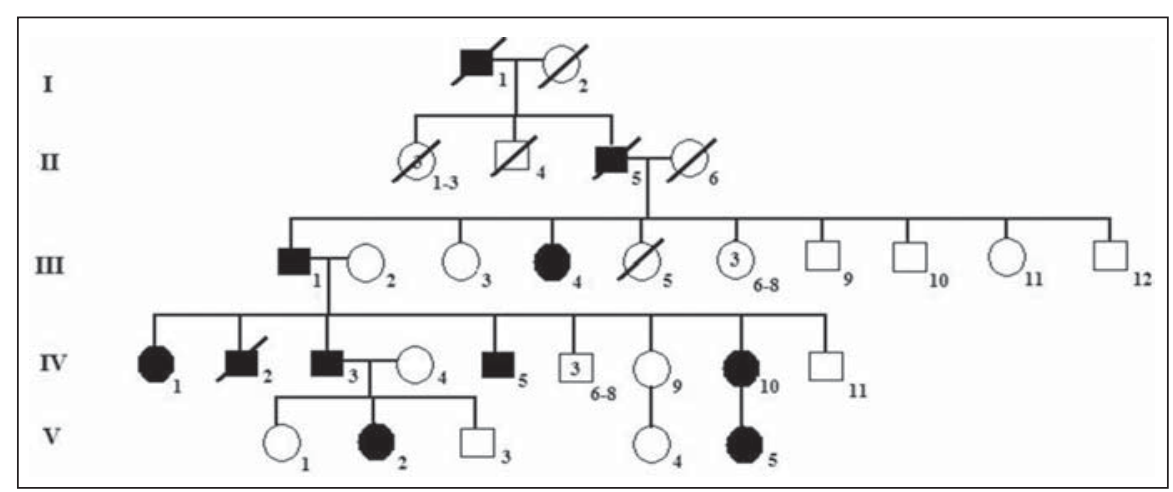

Figure 3. Heredogram of the family with members affected throughout several generations, demonstrating dominant autosomal inheritance. The individual IV-5 corresponds to the patient, and the III-1, to his progenitor, both affected by the condition, as described in the present cases report.

dominant, monogenic autosomal etiology of the condition (Figure 3).

In the patient's progenitor, the individual III-1, clinical evaluation revealed low stature, brachycephalus, cranial bones bulging and frontal bone prominence, open sagittal suture at palpation, subtle exophthalmos, middle facial third hypoplasia, ogival palate, occlusal disharmony and anomalous dentition. Additionally, at pal- pation, hypoplasia of both clavicles was observed, leading to anomalous shoulders mobility. Such a finding was confirmed by radiography of the clavicles (Figure 4).

Because of the generalized occlusal disharmony, absence of teeth, innumerable deep carious lesions and multiple dentigerous cysts, it was opted for complete surgical teeth extraction and making of a total dental prosthesis.

Both patients present clinical manifestations that are different in intensity and variety, thus demonstrating the variable expressivity of cleidocranial dysostosis.

\section{DISCUSSION}

The clinical and radiological findings observed in the present cases correspond to the pathognomonic triad for the diagnosis of cleidocranial dysostosis - presence of multiple supernumerary teeth, partial or total absence of clavicles and failure in sagittal suture and fontanelles closure -, as well as familial recurrence compatible with the dominant, monogenic autosomal etiology. Thus, the diagnoses of cleidocranial dysostosis was established, and the patients were referred for genetic counseling.

Based on the present report, one observes the relevance of the dentist's role in the diagnosis of the condition, since most of times this is the first professional consulted about the patient's complaint. Additionally, it should be highlighted that, during the anamnesis, it is necessary to investigate the familial history, due to the high risk for recurrence.

According to Tanaka et al. and Gassen et al., it is clear that there is a necessity for a multidisciplinary approach in the assistance to patients with cleidocranial dysostosis. Specialists in odontology, psychology, speech therapy, geneticists, endocrinologists and otorhinolaryngologists should be involved ${ }^{(6,7)}$. According to Silva Júnior et al., the early diagnosis of such a condition is extremely important to minimize oral cavity alterations with a view on a functional adaptation and a better quality of life for the individual ${ }^{(8)}$.

\section{REFERENCES}

1. Lovell W. Lovell \& Winter's Pediatric orthopaedics. 6th ed. Philadelphia: Lippincott Williams \& Wilkins; 2006. 


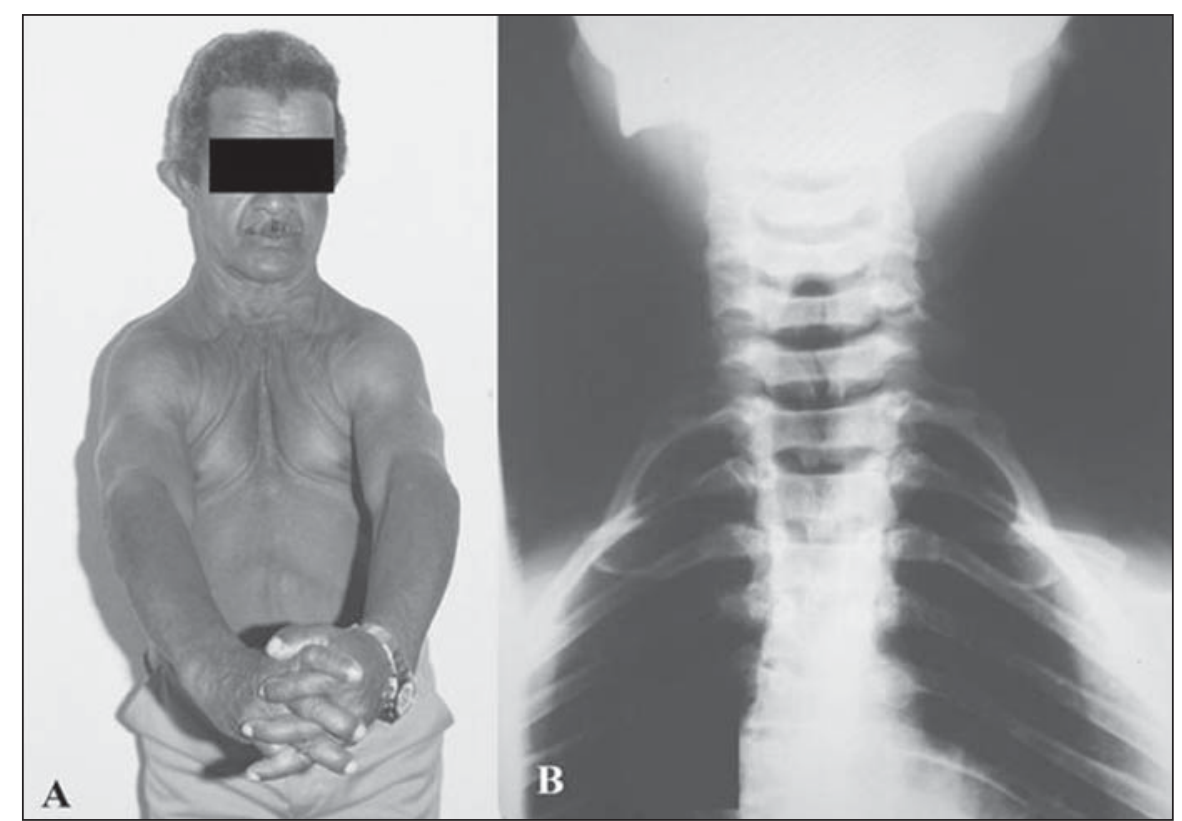

Figure 4. A: Abnormal shoulders mobility. B: Radiography demonstrating bilateral clavicular hypoplasia.
2. Marussi VHR, Mariz FEN, Moraes AC, et al. Disostose cleidocraniana: relato de caso. Rev Imagem. 2008;30:79-82.

3. Serratine ACP, Rocha R. Displasia cleidocraniana - apresentação de um caso clínico. Arq Cat Méd. 2007;36: 109-12.

4. Machado CV, Pastor IMO, Rocha MCBS. Características clínicas e radiográficas da displasia cleidocraniana - relato de caso. RFO UPF. 2010;15 302-6.

5. El-Gharbawy AH, Peeden JN Jr, Lachman RS, et al. Severe cleidocranial dysplasia and hypophosphatasia in a child with microdeletion of the C-terminal region of RUNX2. Am J Med Genet A. 2010;152A:169-74

6. Tanaka JL, Ono E, Filho EM, et al. Cleidocranial dysplasia: importance of radiographic images in diagnosis of the condition. J Oral Sci. 2006;48: 161-6.

7. Gassen HT, Marchiori M, Silva SO, et al. Relato de dois casos familiares de disostose Cleidocraniana. Rev Fac Odont UFP. 2006;11:31-5.

8. Silva Júnior AN, Hernandez PAG, Vargas IA, et al. Displasia cleidocraniana: aspectos clínicos e radiográficos e relato de um caso clínico. Rev Ciênc Méd Biol. 2007;6:122-7. 